\title{
Od teatru okrucieństwa do Grand Guignolu. Śmierć w kinie Andrzeja Żuławskiego
}

ABSTRACT. Nowakowski Jacek, Od teatru okrucieństwa do Grand Guignolu. Śmierć w kinie Andrzeja Zuławskiego [From the theatre of cruetty to Grand Guignol. Death in the cinema of Andrzej Żuławski]. „Przestrzenie Teorii” 5, Poznań 2005, Adam Mickiewicz University Press, pp. 205-212. ISBN 83-232-1605-3. ISSN 1644-6763.

This essay shows the motif of death in the film works of Andrzej Żuławski in the perspective of the theatre of horror. Starting with Trzecia czesć nocy (The Third Part of the Night) (1971) until his late work Szamanka (The Shaman Woman) (1996), this film work is shown as evolving from the patronage of the conception of art of Antonin Artaud, serving the transformation of man up to its peculiar autoparody, which is closer to Grand Guignol. The author proves that escalation of cruelty in his works gradually loses its artistic pretext (justification) ceases to be artistically justified (no longer find artistic justification).

Niczym nowym ${ }^{1}$ nie jest $\mathrm{z}$ pewnością zwrócenie uwagi na perspektywę apokaliptyczną, według której Andrzej Żuławski konstruuje fabuły większości swoich filmów. Nie jest to zwykle perspektywa odległa, zwłaszcza gdy realizuje się ona niejako w ekranowym „tu i teraz” (patrz: Trzecia część nocy); czasami zaś nadchodzi tak szybko, że będzie „tu (i) zaraz" (Opętanie, Szamanka). Jeśli jednak wiemy z całą pewnością, że wyobraźnia artysty ma charakter eschatologiczny, to jej ukonkretnienie się $\mathrm{w}$ dziele ma, mimo pozorów powtarzalności, charakter wcale nie tak jednorodny i jednoznaczny. Dotyczy to zwłaszcza obrazów śmierci, których - jak przystało na piewcę Apokalipsy - jest w dziele Żuławskiego niezmiernie dużo i - co nawet istotniejsze - są one szczególnie eksponowane. Obrazom tym chciałbym poświęcić w tym miejscu więcej uwagi, również ze względu na to, że to właśnie one przyczyniają się w dużej mierze do polaryzacji stanowisk widzów stykających się z twórczością autora Wierności.

Trzecia część nocy (1971), jak to zazwyczaj z debiutami filmowymi bywa, przynosi artystyczny manifest autora, który już w tytule odwołuje się do interesującego go horyzontu kulturowego i ontologicznego. $\mathrm{Na}$ ekranie zagłada spełnia się $\mathrm{w}$ obrazach niemieckiej okupacji w Polsce podczas II wojny światowej. Jeźdźcy Apokalipsy przybywają już w dru-

${ }^{1}$ M.in. M. Martin, Jeździec Apokalipsy, tłum. J. Słodowski, „Film na Swiecie” 1991, nr 383. 
gicj scenie filmu: wrodzy żołnierze na koniach mordują niemal całą rodzinę głównego bohatera - matkę, żonę i syna. Ale, jeśli Apokalipsa może być jakimś początkiem, jest to dopiero początek koszmaru. Zgodnie z przepowiednią, że „ludzie będą szukać śmierci, ale nie znajdą jej”, Michał (Leszek Teleszyński) zapragnie być od tej chwili ślepy, głuchy i niewidzialny, być nikim, wtopić się w złowrogi pejzaż. Nie będzie mu to jednak dane. Wstępując do konspiracji, przyczynia się do omyłkowego aresztowania mężczyzny, którego z nim pomylono. Próbując odkupić swą winę, bohater zaczyna się opiekować pozostawioną samą sobie żoną tamtego i właśnie narodzonym dzieckiem. Lecz czy siła miłości wystarczy, aby ocalić tych, których już raz nie zdołał ochronić? „Swiat się rozsypał. Szczezł. Trzeba się dostosować do tych praw" - mówi ojciec Michała. Ktoś inny dodaje: „Pozostaje tylko okrucienstwo. I miłość, która jest jego odwrotnością".

Okrucieństwo przybiera u Żuławskiego formę monstrualną, wyrażającą się nie tyle w kategoriach ilościowych, ile ,jakościowych”. Obrazy konwulsji, rannych i umierających, wszechobecność krwi, mnogość trupów lub ciał jeszcze żywych, a już poza granicą człowieczeństwa, cial chorych, ułomnych, zniekształconych bólem i skurczami, pokaleczonych, ciał przedmiotów - oto jak wygląda dzieło wojennej Apokalipsy. Śmierć może jednak zbratać się z życiem - mówi artysta - wystarczy tylko znaleźć ogniwo łączące oba te wymiary. W Trzeciej części nocy będą nim wszy, karmione ludzką krwią. Dialektyka ich istnienia na styku życia i śmierci zasadza się na obosieczności ich roli. Z jednej strony roznoszą zarazki tyfusu - śmiercionośnej plagi wojennej, z drugiej to właśnie dzięki nim można opracować szczepionkę do walki z tą plagą. Do badań potrzebne jest tylko mięso, ludzkie mięso...

Czy reżyserska wizja okupowanego Krakowa, a może Lwowa (tam mieścił się Instytut Weigla) z pierwszego pełnometrażowego filmu Andrzeja Żuławskiego jest bardzo odległa wizji Warszawy końca XX wieku z Szamanki (1996), ostatniego jak dotąd polskiego filmu reżysera? I tak, i nie. Różnią się zwłaszcza tym, że w pierwszym z wymienionych filmów dominuje wyraźnie funkcja katarktyczna: bolesny koszmar okupacji ma charakter niemal fizyczny, namacalny, lecz usprawiedliwiony „okropieństwami wojny”. W drugim przypadku widz nie wychodzi z konfrontacji $\mathrm{z}$ dziełem oczyszczony, lecz udręczony, $\mathrm{z}$ niemalejącym poczuciem odrazy. Zbieżności tematyczne obu filmów polegają z kolei na tym, że reżyser niezmiennie pokazuje śmierć w ten sam sposób. Co więcej, paralele między filmami wzmacnia motyw odrażających, w powszechnym mniemaniu, stworzeń. W Szamance oglądamy scenę w rzeźni, gdzie do maszyny do mielenia mięsa dostaje się żywy szczur. Gdy zechcemy potraktować scenę tę metaforycznie, pojawia się pewien problem. W debiucie reżysera przenośnia była czytelna: człowiek oddający swe ciało wszom, przezwy- 
ciężał niejako akt śmierci na rzecz przyszłego życia. W ostatnim z omawianych filmów znacznie trudniej o jednoznaczne odczytanie. Nie sposób chyba mówić o zrównaniu życia i śmierci w obrazie maszyny tnącej na miazgę to, co żywe, i to, co martwe. Interpretacja musi być inna. Wobec nadciągającej Apokalipsy, wszyscy, nawet ci jeszcze żywi, jesteśmy tylko mięsną karmą w odwiecznym cyklu wegetatywnym świata. Gdyby jednak taką konstatację odebrać na serio byłaby to manifestacja nihilizmu, jak sądzę, raczej bezwiedna. W tym sensie oba filmy dzieli zbyt wiele...

Zasadą estetyczną rządzącą światem Żuławskiego jest turpizm. Termin ten kojarzony i rozumiany jest w Polsce zwykle jako pochodna reakcji Juliana Przybosia na utwory poetów, którzy manifestowali w nich swoje postawy antyestetyczne. Obok Stanisława Grochowiaka, Andrzeja Bursy czy Rafała Wojaczka, których poezja przypomina nam o brzydocie rozumianej jako prawda życia, podobne spojrzenie na biologię i ciało reprezentowali niektórzy artyści filmu. Warto pamiętać, że Andrzej Żuławski rozpoczynał swoją karierę filmową jako asystent Andrzeja Wajdy, m.in. przy Samsonie (1961) oraz Popiołach (1965). Wkrótce też dał się poznać jako kontynuator estetyki i temperatury emocjonalnej dzieł starszego kolegi, tyle że w wydaniu ekstremalnym. Jeśli szukać bliższych związków w obrębie interesującego nas pola badawczego, warto pamiętać, że elementy turpistyczne pojawiają się w dwóch najważniejszych filmach Wajdy z początków jego drogi twórczej: w Kanale (1956) i Popiele $i$ diamencie (1958). W pierwszym zwraca uwagę tytułowe miejsce akcji, będące nie tylko metaforycznym obrazem piekła wojny, ale tė̇ jego dosłowność, każąca patrzeć nań i myśleć o nim z odrazą. W drugim ze wspomnianych filmów finałowa scena śmierci Maćka Chełmickiego (Zbigniew Cybulski) na śmietniku także wywołuje symboliczne konotacje, a jednocześnie poraża dysonansem zbudowanym na zderzeniu metafizyki ludzkiej śmierci z krajobrazem przepełnionym rozkładającymi się odpadami konsumpcyjnej cywilizacji.

Żuławski nawiązuje do stylów i okresów, które często wyrażały estetykę brzydoty, zwłaszcza do baroku i ekspresjonizmu. Sam natomiast jest - i to również łączy go z twórczością Andrzeja Wajdy - spadkobiercą tradycji modernistycznej. Reżyser postępuje podobnie jak artyści z początku XX wieku.

Europejską sztukę wysoką - zauważa Tomasz Jopkiewicz - chciano połączyć z tym, co niskie, naprawdę niskie. Coś podobnego usiłuje, mniej lub bardziej konsekwentnie, czynić Żuławski. W ten sposób wykreował świat, w którym występuje jarmarczna apokalipsa. Świat w stanie widowiskowego, malowniczego rozkładu, dekadenckiego łamania wszelkich norm etycznych, świat zaczadzony złem².

2 T. Jopkiew icz, Najważniejsze to krzyczeć. Niespodziewany triumf moderny, „Film” 1989 , nr 23. 
W polskim kinie nikt chyba nie może równać się z tym autorem w rehabilitacji brzydoty jako kategorii artystyczno-estetycznej. O niebezpieczeństwach uproszczenia tej optyki Maria Gołaszewska pisała:

Gdy genezy brzydoty jako przeżycia czy odczucia szukać będziemy w zjawiskach prostych jak zapach, dotyk, skojarzenia fizjologiczne, czyli zejdziemy na teren estetyki zminimalizowanej, wówczas istotnie możemy oddzielić dość jednoznacznie piękne, czyli miłe, budzące pozytywne doznania od brzydkiego, czyli budzącego doznania negatywne ${ }^{3}$.

Jak widać, dość łatwo potraktować turpistyczną sztukę jako konsekwencję prostych odczuć i impulsów, których doświadczamy w życiu codziennym. Niestety, taki odbiór zbyt mocno zaciążył na recepcji filmów Żuławskiego, a przecież jest nie tylko powierzchowny, ale też fałszywy, ograniczający się zwykle do sfery decorum jego filmów. Okrutny, ale i ludzki jest świat Diabła (1972). Fabuła, rozgrywająca się podczas rozbioru Polski, który wyznacza data 1793 roku, opowiada o losach Jakuba (Leszek Teleszyński), uwolnionego z przyklasztornego domu dla obłąkanych przez tajemniczego człowieka, który okazuje się diabłem (Wojciech Pszoniak). Na oczach Jakuba rozpada się znany mu świat. Więzi rodzinne, społeczne, a nawet motywacje podtrzymujące funkcje życiowe czy psychiczne ulegają rozkładowi. Jakubowi jako obłąkanemu latwo jest wskazać drogę, którą ma iść, a zwłaszcza - powiedzieć, co czynić. Oczywiście zabijać i oczyszczać ohydny, zdeformowany i amoralny świat. Motywacje okrucieństwa pokazanego w tym filmie są dość czytelne. Jego siłą napędową jest zło wojny i okupacji, tak więc zamyka się błędne koło i zło rodzi zło. Jakub jest podobny do innych bohaterów kina Zuławskiego: ludzi szukających idei - zwykle na ślepo, postaci nieuformowanych i niepełnych, które bezwiednie lub w sposób opaczny wcielają w czyn pomysły i idee innych, podążając prosto w obłęd i śmierć. Taki właśnie jest Michał z Trzeciej części nocy, taki jest też antropolog (Bogusław Linda) z Szamanki, którego odkrycie mumii zamordowanego szamana sprzed dwóch i pół tysiąca lat niczego nie nauczy. Cyniczny i wiarołomny, tak naprawdę zostaje poddany presji sił, których, mimo swego wykształcenia, nie rozumie. Ginie podobnie jak swój zmumifikowany poprzednik z rąk kochanki (Iwona Petry). Rytuał dopelnia się więc cyklicznie. Podobnie kończy swe życie Marek Zwycięzca (Andrzej Seweryn) z filmu $N a$ Srebrnym Globie (1977), który ukrzyżowany niczym Mesjasz, nie jest pewien Siły, która go do tego doprowadziła. W najszerszym planie adaptacja obszernych fragmentów Trylogii Księżycowej Jerzego Żuławskiego jest kolejną filmową opowieścią, pokazującą, jak żadna społeczność nie

${ }^{3}$ M. Gołaszewska, Fascynacja zlem. Eseje z teorii wartości, Warszawa-Kraków 1994, s. 233. 
może obyć się bez religii czy idei, które szybko, poprzez ludzkie czyny, zamieniają się w swoje karykatury i prowadzą do śmierci nikczemników, którym nie starczyło wiedzy czy sił, aby je zrozumieć. Paroksyzm, delirium, konwulsje - słowem, stany gorączkowe, chorobowe i przedśmiertne są dla nich stanem normalnym.

Ze śmiercią, którą bohaterowie zadają innym i która w końcu staje się ich udziałem łączy się bezpośrednio obłęd czy paranoja. Ataki i stany szaleństwa, lunatyzmu są też rodzajem wyzwolenia, momentalnego olśnienia, może nawet jakąś formą obrony. Nietrudno domyślić się, że Żuławski podąża tu tropem swojego ulubionego pisarza - Fiodora Dostojewskiego - któremu zawdzięcza choćby inspirację dla dwóch dzieł francuskich: Kobiety publicznej (1984) i Szalonej miłości (1985). Lecz w filmach tu omawianych reżyser idzie najdalej, ponieważ obłęd ich bohaterów znajduje swój wyraz w skrajnym okrucieństwie, którego są świadkami i uczestnikami. Najwyraźniej widać to w Diable. Jak zauważa z amerykańskiej perspektywy Michael Atkinson, w utworze tym -

młody antyrojalista manipulowany jest przez widmo tajemniczego demiurga/rządu do zdrady swoich ideałów, masakrując praktycznie każdego wokół siebie. Film będąc żywym obrazem ludzkiego cierpienia i rozpusty, czyni jednocześnie drastyczną historię opowiedzianą przez takiego mistrza jak Ken Russell dziełem księdza pozbawionego wyobraźni ${ }^{4}$.

Słowa te, mimo że napisane dość przekornie i z nuta podziwu, zwracają naszą uwagę na jeszcze jeden aspekt twórczości Andrzeja Żuławskiego, związany nierozerwalnie z zawartym w niej wizerunkiem śmierci - mianowicie wybujałym, choć pozbawionym upiększeń i eufemizmów, erotyzmem.

W przypadku Diabla i Szamanki (a także wielu filmów zagranicznych) możemy już mówić o panerotyzmie, często przedstawianym w wymiarze orgiastycznym. U Żuławskiego nawet miłość łączyć musi się z fizjologią. Widząc jej owoce w Trzeciej części nocy, obserwujemy poród pokazany w sposób niezwykle naturalistyczny, dodatkowo poprzedzony gwałtownym obrazem śmierci. Trudno, rzecz jasna, o intymność w czasie apokalipsy, dlatego akt miłosny będzie zawsze gorączkowy, pospieszny i niezgrabny, a nawet odpychający, czego koronnym przykładem będą sceny z Szamanki. Wcześniej, zwłaszcza w Diable, reżyser raczy nas scenami orgii na zamku, w środek której wkracza Jakub z brzytwą w ręku. Plątanina nagich ciał, niesionych rytmem charakterystycznej muzyki Andrzeja Korzyńskiego, szybko zostaje rozsupłana narzędziem, którym bohater posługuje się jak mieczem. W szale zespolenia jego wejście prze-

${ }^{4}$ M. Atkinson, Trouble every day. From amour fou to primal scream: inside the movie madhouse of Andrzej Zulawski, „Film comment” 2003, nr 1. 
staje być dysonansem. Kamera niczego nam nie oszczędza. Nie ma tu żadnego markowania ciosów czy zabiegów eufemizujących erotyczne rozpasanie. W momencie ostatecznego przełomu można sobie pozwolić na więcej niż zwykle, właściwie można sobie pozwolić na wszystko. Dlatego tèz

orgia bynajmniej nie jest powrotem do seksualności naturalnej, nieokreślonej. Jest to życie seksualne bezładne, związane odczuciem świata na wywrót, wywołanym przez uchylenie wszystkich niemal zakazów ${ }^{5}$

Jej uczestnicy z filmu Żuławskiego nie wiedzą jednak, że wyzwolenie, którego pewnie się spodziewali uczestnicząc $\mathrm{w}$ tym rytuale, przyjdzie z zewnątrz, a ten, który je przyniesie, nie będzie pytał o zgodę i formę, w jakiej ma się ono objawić.

W Na Srebrnym Globie niektórzy z uczestników zbiorowej ekstazy zostają później powbijani na pale. Zanim do tego dojdzie, kobiety z grupy planetarnych osadników odkryją rozkosz, której wcześniej nie znały. Stanie się to możliwe dzięki kontaktom z Szernami znającymi prawdopodobnie istotę dobra i zła. Jednak ceną tych związków były obłąkanie i śmierć dotykająca oba gatunki. Śmierć Szernów - z ich boskiej perspektywy - miała jednak znaczenie drugorzędne. Te zaś z kobiet, które miały możliwość poznania choćby seksualnego wymiaru ich natury, będą tęsknić do przeżytych doświadczeń jak do święta. Mają tu uzasadnienie słowa Georgesa Bataille’a:

W sposób zupełnie zasadniczy to, co sakralne, jest tym, co zakazane. Jednakże chociaż sakralne, zakazane, zostaje usunięte poza obręb życia świeckiego, to przecież ma ono i tak większą wartość niż pierwiastek świecki, który je usuwa. Nie jest to już pogardzana zwierzęcość; często jej obraz nadal zachowuje kształt zwierzęcy, ale teraz jest ona czymś boskim. Jako taka, owa usakralizowana zwierzęcość ma w stosunku do życia świeckiego ten sam sens, jak negacja natury (a w konsekwencji - życia świeckiego) ma w stosunku do czystej zwierzęcości. [...] Tym, co zostaje zanegowane przez życie boskie, jest zawsze zależność; teraz jednak zakwestionowaniu ulega świadome i dobrowolne zniewolenie świata świeckiego ${ }^{6}$.

Tym, który zrozumiał Szernów, był Marek Zwycięzca. Poznając ich moc i wszechwiedzę, sam uciekł w obłęd; na pewno zaś należał do nielicznych, którzy odrzucili pogląd o zwierzęcości prawowitych mieszkańców Srebrnego Globu.

Stawiam więc tezę, której zasadność udowadniam na tych stronach, że autor Trzeciej części nocy, Diabła, Najważniejsze to kochać, Na Srebr-

${ }^{5}$ G. Bataille, Historia erotyzmu, tłum. I. Kania, Kraków 1992, s. 111.

6 Tamże, s. 78. 
nym Globie posługuje się formułą teatru okrucieństwa, stworzoną przez Antonina Artauda. Czy uczynił to świadomie czy bezwiednie, to już sprawa drugorzędna. Dużo bardziej istotne są rezultaty, które udało mu się osiągnąć. Na gruncie filmowym reminiscencje Artaudowskie znajdujemy między innymi w twórczości Fernando Arrabala czy Romana Polańskiego, o czym ciekawie pisała Mariola Jankun-Dopartowa7. Okrucieństwo sztuki Żuławskiego miało u swego źródła uświadomienie odbiorcy kinowego spektaklu możliwości przemiany czlowieka, poddania go intensywnej terapii. Ten typ filmowego spektatora definiuje polski monografista Artauda, odnosząc się do jego pierwszych, bezpośrednich widzów. Otóż twierdzi on, że czlowiek poddany chorobliwej gorączce obrazów, sam za chwilę jej ulegnie.

Ale właśnie w rozpasaniu zarazy - pisze Leszek Kolankiewicz - zawiera się obietnica wyzdrowienia. A przez to epidemia jest zbawienna. Najpierw dlatego, że oczy widza otwierają się na ukryte zwykle theatrum obrazów i figuracji, że oto budzi się on tak, jak budzi się wokół niego życie. Wysadzony z kolein normalności, bez ustanku wstrząsany - poznaje. Rozpoznaje prawdziwą swą istotę - doświadczając przy tym niebywałego, ostatecznego spotęgowania osobowości i poznaje prawdziwą naturę świata. Patrząc na zewnątrz i zaglądając do swego wnętrza, widzi odwieczny spór zasady dobra z zasadą zła. Co więcej, rozpoznaje sens zła. Całe to przesilenie okazuje się złem wyższym, bo służy radykalnemu rozwiązaniu kryzysu, którego nic innego nie może już naprawić. I tak oto sprawy świata człowieka postawione zostają na jedną kartę. Po tym teatrze pozostaje tylko rozwiązanie ostateczne. Albo śmierć - a nie ma co żałować ani chorego świata, ani chorego człowieka - albo zupełne oczyszczenie ${ }^{8}$.

Wobec nadciągającej Apokalipsy nie ma więc sensu uciekać, tym bardziej jeśli ona realizuje już swe dzieło.

Niestety, opisana wyżej intencja reżyserska nie do końca sprawdza się w Szamance. Jej bohaterka, pozornie kierująca się tylko zwierzęcym instynktem i wykorzystywana przez mężczyzn, w rzeczywistości potrafi nimi pokierować. Jako reprezentantka siły animistycznej i pierwotnej stanowi wyraźne przeciwieństwo antropologa Michała, który prywatnie ulega namiętnościom, lecz do pracy uzbraja się w „mędrca szkiełko i oko". Szamanka ta to postać szczególna. Często naga, z rozchylonymi ustami, gwałtowna i rozbiegana, przypomina inne bohaterki filmów Żuławskiego, tyle że u niej cechy te zostały zwielokrotnione i skarykaturyzowane. Kiedy więc w finale szamanka-modliszka uśmierca po akcie płciowym swego kochanka i otwiera mu czaszkę, by wyjeść masę mózgową, trudno już potraktować serio wywód reżysera. Finałowe zbratanie seksu i śmierci miałoby jednak w takim przypadku metaforyczne uza-

${ }^{7}$ M. Jank un-Dopartow a, Labirynt Polańskıego, Kraków 2000, s. 88-93.

8 L. Kolankiewicz, Swięty Artaud, Gdańsk 2001, s. 147-148. 
sadnienie: należy porzucić myślenie na rzecz odczucia, konceptualizm zastąpić sensualizmem, wtedy drastyczne otworzenie czaszki może stanowić symbol pokonania ograniczeń naszej konstrukcji cielesnej, która jest tylko sztuczną granicą ubranego w powłokę ducha czy jaźni. Czy Michał jako bezcielesny byt jest wreszcie wolny? Pozostawmy to pytanie bez odpowiedzi...

Zgadzam się z filmoznawcą, który pisze:

Kwestia odkrytego szamana, wybuchu materiału radioaktywnego, który bynajmniej nie pociąga za sobą zagłady, a przede wszystkim znajomość dotychczasowych obrazów twórcy Borysa Godunowa wymagają rezygnacji ze zdroworozsądkowych wnioskowań, właściwych dla percepcji świata codziennego ${ }^{9}$.

Tyle, że ten rozsądek dawno już za nami. Andrzej Żuławski w początkach kariery potrafił przełożyć swoje intencje artystyczne na język filmu $w$ sposób nie budzący sprzeciwu u publiczności. Jeśli nie zawsze w sferze intelektualnej czy estetycznej, to na pewno w sferze przeżycia, rozumianego jako odczucie autentyczności sztuki, a nie symulacji ograniczonej taką czy inną konwencją. Dlaczego zatem w Szamance, ćwierć wieku od debiutu, Żuławskiemu bliżej do Grand Guignol? Wydaje się, że reżyser konstruuje zbyt jednoznaczne alibi dla wydarzeń i swoich bohaterów. Wybuch bomby masowego rażenia przypomina raczej konwencję science fiction. Nie tylko w tym rzecz. Chodzi raczej o to, że okropność, makabra i niesamowitość w Szamance, inaczej niż w poprzednich filmach, zbyt często ocierają się o humor. I nie tylko ten czarny czy nawet absurdalny, ale humor bezwiednej parodii. Czym innym był jednak spektakl Grand Guignol, jeśli nie parodią tego, co w sztuce - okrutnej wzniosłe, tragiczne czy ostateczne? Sztuka deformująca samą siebie poprzez ironię i przejaskrawienie jest parodią. Jeśli czyni to niezależnie, wymykając się z rąk swemu autorowi, staje się autoparodią. Sądzę, że jest to casus Szamanki, w której intencje twórcy rozminęły się z materią dzieła i reakcją publiczności.

Jeśli więc teatr okrucieństwa wczesnych filmów Andrzeja Żuławskiego został w Szamance mimowolnie zastąpiony przez Grand Guignol, to akademicka Wierność (2000) jest próbą przesunięcia akcentów na inne wartości artystyczne, ale to już temat na całkiem inną opowieść...

9 J. Niedziela, O emocjach towarzyszqcych "Szamance” Andrzeja Żulawskiego, w: Na rubieżach ponowoczesności. Szkice o filmie wspótczesnym, red. K. Klejsa i G. Skonieczko, Kraków 2000, s. 43. 